Journal of Social Sciences 5(2): 123-133, 2009

ISSN 1549-3652

(C) 2009 Science Publications

\title{
An assessment of Urban Quality of Life by Using Analytic Hierarchy Process Approach (Case study: Comparative Study of Quality of Life in the North of Iran)
}

\author{
${ }^{1}$ Sedigheh Lotfi and ${ }^{2}$ Karim Solaimani \\ ${ }^{1}$ Department of Urban Planning, University of Mazandaran, Iran \\ ${ }^{2}$ Remote Sensing and Geographic Information Science Center, \\ University of Agriculture and Natural Resource Sciences, Sari, Iran
}

\begin{abstract}
Problem Statement: Researches of quality of life are concentrated mainly on the urban nature in the recent years and the urban quality of life gained many attentions in empirical studies. The concept of urban quality of life is a multi-dimensional and complex issue. So, needless to say that this concept can be used in planning when there is an appropriate and reliable framework for measuring. Approach: The present study tried to create a framework on the base of Analytic Hierarchy Process (AHP) for objective measuring of urban quality of life and then it would be applied for a comparative study of two northern cities of Iran. Results: The results showed that using analytic hierarchy process model creates opportunity to involving the different groups' views of urban users with respect to their duties and functions in the stage of criteria weighting. Conclusion: This process not only provided an appropriate bed for objective measuring of urban quality of life but it facilitated the participation of urban authorities in the process of measuring and analyzing the urban quality. Also one of the advantages of the model was its high level of clarity and simplicity which could be perceived by all urban decision makers.
\end{abstract}

Key words: Objective Urban Quality of Life (UQOL), Analytical Hierarchy Process (AHP), measuring, comparative study

\section{INTRUDUCTION}

Researchers from a variety of disciplines have studied Quality Of Life (QOL) since the 1930s ${ }^{[53]}$. They tried to identify the components of QOL and compared various geographical areas such as cities, states and nations by means of QOL indices that they developed ${ }^{[2,3,25,48,47]}$. In addition to the researchers, international organizations such as $\mathrm{UNDP}^{[51]}$ developed its own measures for QOL. The desire to improve the quality of life in a particular place or for a particular person or group is an important focus of attention for planners ${ }^{[28]}$.

An important reason for such an interest in QOL lies in the question of effective allocation of scarce resources ${ }^{[32]}$. In fact improvement of life quality in each society is one of the important aims of public policies. In recent years studies of life quality have mainly concentrated on the urban nature and urban quality of life gained much attention among the researchers. Clearly the increase of urban population and the increasing tendency for living in the city is one of the main incentives to expand an independent movement on life quality researches.
The urban QOL concept gains more importance when it is considered that the world population is expected to reach somewhere between 7.6-9.4 billion $^{[22]}$ and the urban population is expected to reach $50 \%{ }^{[47]}$ in the beginning of the next century. The multi-dimensional character and evolutional nature of quality of life led to different interpretations which made the investigation difficult. So the recent research on the quality of life emphasis on the quality of measuring this concept in the cities. Clark and $\mathrm{Kahn}^{[7]}$ used a two-stage hedonic approach to estimate willingness to pay for urban cultural amenities such as muse ums, theater, dance, instrumental music and zoos. For a typical city, the marginal benefits from improving these cultural goods are estimated to be in the \$.85-\$57.9 mil lion range for an additional theater and an additional zoo, respectively. Stover and Leven ${ }^{[48]}$ examined the importance of functional form in estimating values for the quality of life in urban areas. Values of local amenities are assessed from the interaction between the labor and real estate markets. Alternative theoretical specifications are consistent with previous study but yet different. Results show quality of life rankings for 253 urban counties are highly sensitive to alter native model specifications.

Corresponding Author: Sedigheh Lotfi, Department of Urban Planning, University of Mazandaran, Iran 
In Giannias ${ }^{[16]}$ research, a structural approach to hedonic equilibrium models is used to estimate a quality of life ranking of five cities in the United States. Quality of life is a function of housing and neighborhood characteristics (number of rooms, air quality and travel time to work) and of city-wide amenities. Resulting quality of life values and rankings are different from those implied by previous study. Michalos and Zumbo ${ }^{[33]}$ predicted life satisfaction from 14 life domains for seven different time periods between 1979 and 1997. Of those domains relating to urban QOL, housing was significant in six time Objective and subjective indicators of urban quality of life 81 periods, recreational activity in five, transportation in four, government services in three and residential area in two (though it was not included in one time period). Thus, satisfactions in various urban domains predict overall life satisfaction.

Ulengin et $a l .{ }^{[50]}$ used a multidimensional approach to urban quality of life. The purpose of this study is to model the priorities, expectations and needs of the inhabitants of Istanbul, a city with a population of about 10 million, from a multidimensional perspective. In this way, effective allocation of the city's resources can be achieved to improve the Quality Of Life (QOL) for such a large number of people, which is the primary concern of the local authorities as well as the urban planners. For this reason, a survey is conducted in Istanbul so that the priorities of the inhabitants are revealed and the city where they would like to live is portrayed. The data obtained are used as input for hierarchical conjoint analysis. The survey is primarily based on the evaluation of hypothetical, experimentally designed city profiles for four different constructs on a $0-10$ rating scale. The relative importance of the constructs is estimated through the eigenvector approach.

McCrea et $a l .{ }^{[30]}$ examined different geographic levels of subjective urban QOL. Regional satisfaction was best predicted by evaluations of regional services (such as health and education) and the cost of living, while evaluations of environmental and urban growth problems were significant predictors of regional satisfaction for younger persons. Neighborhood satisfaction was best predicted by evaluations of social interactions, neighborhood crime and public facilities (parks, libraries), while housing satisfaction was predicted best by age of home and home ownership. Richards et al. ${ }^{[39]}$ investigate the factors that are most important in improving the quality of life of residents in informal housing as well as the main obstacles to a better quality of life. It uses regression analysis to obtain an understanding of the kinds of issues which shape quality of life in these areas and concludes by suggesting several research directions which would improve our knowledge of quality of life for informal settlement residents.

The present study attempts to provide an appropriate framework by using analytic hierarchical process for objective measuring of urban quality of life. Then it will conduct a comparative study in two urban centers of Iran. Such study not only provides a good context for measuring quality of life but it facilitates the participation of urban authorities and local decision makers to take part in the process of planning.

Measuring quality of life: A number of researchers such as Mc Call ${ }^{[29]}$, Mayers ${ }^{[35]}$, Davidson and Cotter ${ }^{[10]}$, O'Brien and Ayidya ${ }^{[36]}$, Grayson and Young ${ }^{[17]}$, Diener and Suh $^{[12]}$, Turksever and Atalik ${ }^{[49]}$ have reviewed literature on QOL and there is general agreement that a meaningful definition of QOL must recognize that there are two linked dimensions to the concept, namely a psychological one and an environmental one. Dissart and Deller ${ }^{[13]}$ argue that "A person's quality of life is dependent on the exogenous (objective) facts of his or her life and the endogenous (subjective) perceptions he or she has of these factors and of himself or herself." Grayson and Young ${ }^{[17]}$ note that "there appears to be a consensus that in defining quality of life there are two fundamental sets of components and processes operating: those that relate to an internal psychological mechanism producing a sense of satisfaction or gratification with life and those external conditions which trigger the internal mechanism."

With respect to the first dimension other terms have been used, for example individual/ personal QOL, subjective well-being or life satisfaction. For the second dimension there are different levels and terms used for example urban QOL, community QOL, quality of place, environmental $\mathrm{QOL}^{[28]}$. Since the concept of 'quality of life' is very complex, often it is said that integrating the two dimensions can provide a good picture of quality of life for a person or a place. Dissart and Deller ${ }^{[13]}$ reasoning that "quality of life for an individual is depended to the objective and external realities and his (her) subjective and internal perception of these factors and himself too." As noted already the concept of quality of life is complex and it could be used in the field of urban planning when an appropriate and reliable framework is devised for measuring it.

There are two sets of indicators for the measuring quality of life which most of the researchers are agreed with them. The first set is Objective Indicators which refers to the objective and visible aspects of the urban life and are defined by different elements. For example 
the number of hospitals in a city, unemployment rate, the volume of crime and the area of urban green spaces. The second set is Subjective Indicators which tries to measure and quantify the citizens' satisfaction from the urban welfare. For instance satisfaction of people from health care accessibility, access to job, satisfaction of urban security or access to green spaces.

There are two main approaches for measuring urban quality of life in the literature which is accepted by the most of the researchers. First one is Objective Urban Quality of Life and the second approach is Subjective Urban Quality of Life. However the citizen satisfaction from different aspects of urban life would not be study by this approach but the objective indicators are measured. In this approach the secondary data are used for indicator definition and is depended to the different statistics of the city in some extend. Objective urban QOL studies typically include many objective characteristics of the urban environment, often combining or weighting objective indicators to generate an objective urban QOL ranking for places $^{[2,3,6,43,48,50]}$.

Studies on subjective urban QOL have found that subjective evaluations of many aspects of the urban environment can contribute to satisfaction in urban domains and overall life satisfaction ${ }^{[30,33,45,46,49]}$. The urban quality of life is measured by using the subjective indicators and instead of secondary data, the citizens are asked (questionnaires, interview...) directly for the level of their happiness about different aspects of urban life. Measuring subjective indicators are more time consuming and costly, however the results are more logic and real than the first approach.

Empirical research provides support for the generalization that correlations between objective indicators and relevant life satisfaction domains are often weak and generally lower than correlations between life satisfaction domains and overall life satisfaction $^{[31]}$. Consequently, the two sets of objective and subjective criteria are used for measuring the quality of life in the recent years.

McCrea et al. ${ }^{[31]}$ in their research linked two types of indicators using Geographical Information Systems (GIS) to both locate respondents to the 2003 Survey of Quality of Life in South East Queensland and also to gather objective indicators about their urban environment within the region with regard to services, facilities and overcrowding. Using Structural Equation Modeling (SEM), the strength of the relationships between these objective indicators and subjective indicators was examined. The results show that relationships between objective and subjective indicators of urban QOL can be weak and suggests care should be taken when making inferences about improvements in subjective urban QOL based on improvements in objective urban QOL. Santos and Martins $^{[40]}$ described the monitoring system of the urban quality of life developed by the Porto City Council, a new tool being used to support urban planning and management. The two components of this system-a quantitative approach based on statistical indicators and a qualitative analysis based on the citizens' perceptions of the conditions of life-are presented. It is argued that, in order to achieve a deeper understanding and more effective measurement of urban quality of life, both kinds of measurements are useful and complement each other.

The recent researches show that using both of objective and subjective indicators is the most appropriate way to measuring and the using its results for urban planning. In fact a system should be designed which monitor both sets of indicators continuously and then present the results for urban planners and local decision makers.

What is AHP? The Multi Criteria Decision Making (MCDM) is a set of techniques (e.g., sum of weights or conversion analysis) which is able to weight and score a range of criteria and then the scores are ranked by the expertise and other related interested groups ${ }^{[19]}$. The MCDA techniques are spatial in much degree. In fact, criteria are different among the number of decision in space $^{[27]}$. However, despite the potential of MCDA model for integration to deal with spatial units problems, it gained attention only in a certain period of times in some practical researches and managerial limits $^{[15]}$. Urban planners used the strategy of MCDA integration for dealing with spatial issues from $1990 \mathrm{~s}^{[38]}$. A city system can not be studied only by considering the simple concepts like land use or traffic. Now planners need to develop and deepen their understanding about a city system by analyzing a various socio-economic and political indicators. The issues which need to be dealt at same times create a condition which many alternatives should be tested and integrated to improve ${ }^{[26]}$.

Nowadays, there are numbers of MCDM methods available for selection e.g. Multi-Attribute Utility Theory (MAUT), Multiobjective Programming (MOP), Novel approach to imprecise assessment and decision environments (NAIADE), Analytical Hierarchy Process $(\mathrm{AHP})^{[11]}$. The AHP approach, developed by Satty ${ }^{[41]}$, is one of the more extensively used MCDM methods. The AHP has been applied to a wide variety of decisions and the human judgment process ${ }^{[24]}$. This technique is one of the MCDA methods with many capabilities 
which is used in different scientific disciplines. The previous researches show that the technique of MCDA which is known AHP is very suitable for solving complicated issues ${ }^{[54]}$. It is widely applied to human fields such as resources allocation, project design, planning for urban development, maintenance management, policy evaluation ${ }^{[1,5,8,41,44]}$.

This method is very suitable for complex social issue in which intangible and tangible factors cannot be separated $^{[23]}$. Obtaining solutions in the AHP is not a statistical procedure, because it can help either a single decision maker or a decision group to solve a MCDM problem $^{[4]}$. One of the most important advantages of AHP relates to its ability to measure quantitative and qualitative characteristics of a decision ${ }^{[21]}$. In addition AHP is flexible to allow revision. The decision makers can expand the elements of the hierarchy and change the expert judgments from time to time.

Applying the AHP procedure involves three basic steps: (1) Decomposition, or the hierarchy construction; (2) Comparative judgments, or defining and executing data collection to obtain pair-wise comparison data on elements of the hierarchical structure and (3) Synthesis of priorities, or constructing an overall priority rating ${ }^{[18]}$. In first stage, the decision makers need to break down complex multiple criteria decision problems into its component parts of which every possible attributes are arranged into multiple hierarchical levels.

The criteria and sub-criteria are not each equally important to the decision at each level of the hierarchy and each alternative rates differently on each criteria. AHP can provide an analytical process that is able to combine and consolidate the evaluations of the alternatives and criteria by either an individual or group involved in the decision-making task ${ }^{[9]}$.

One notes that two elements being compared at a given time greatly reduces the conceptual complexity of an analysis. This simplification involves assumptions that Satty ${ }^{[41]}$ and others ${ }^{[34,37]}$ considered reasonable. Given a pair-wise comparison, the analysis involves three tasks: (1) Developing a comparison matrix at each level of the hierarchy starting from the second level and working down, (2) Computing the relative weights for each element of the hierarchy and (3) Estimating the consistency ratio to check the consistency of the judgment ${ }^{[4]}$. The comparisons can be carried out through personal or subjective judgments ${ }^{[20]}$.

The 9-point scale used in typical analytic hierarchy studies is ranging from 1 (indifference or equal importance) to 9 (extreme preference or absolute importance) (Table 1). This pair-wise comparison enabled the decision maker to evaluate the contribution of each factor to the objective independently, thereby simplifying the decision making process.
Table 1: 9-point intensity of relative importance scale

\begin{tabular}{|c|c|c|}
\hline $\begin{array}{l}\text { Intensity of } \\
\text { importance }\end{array}$ & Definition & Explanation \\
\hline 1 & Equal importance & $\begin{array}{l}\text { Two activities contribute } \\
\text { equally to the objective }\end{array}$ \\
\hline 3 & $\begin{array}{l}\text { Weak importance } \\
\text { of one over another }\end{array}$ & $\begin{array}{l}\text { Experience and judgment } \\
\text { slightly favor one activity } \\
\text { over another }\end{array}$ \\
\hline 5 & $\begin{array}{l}\text { Essential or strong } \\
\text { importance }\end{array}$ & $\begin{array}{l}\text { Experience and judgment } \\
\text { strongly favor one activity } \\
\text { over another }\end{array}$ \\
\hline 7 & $\begin{array}{l}\text { Demonstrated } \\
\text { Importance }\end{array}$ & $\begin{array}{l}\text { An activity is strongly } \\
\text { favored and its dominance } \\
\text { Is demonstrated in practice }\end{array}$ \\
\hline 9 & Absolute importance & $\begin{array}{l}\text { The evidence favoring one } \\
\text { Activity over another is of } \\
\text { the highest possible order } \\
\text { of affirmation }\end{array}$ \\
\hline $2,4,6,8$ & $\begin{array}{l}\text { Intermediate values } \\
\text { between the two } \\
\text { adjacent judgments }\end{array}$ & $\begin{array}{l}\text { When compromise is } \\
\text { needed }\end{array}$ \\
\hline $\begin{array}{l}\text { Reciprocals of } \\
\text { above nonzero }\end{array}$ & $\begin{array}{l}\text { If activity } i \text { has one } \\
\text { of the above nonzero } \\
\text { numbers assigned } \\
\text { to it when compared } \\
\text { with activity } j \text {, then } j \\
\text { has the reciprocal value } \\
\text { when compared with } i \text {. }\end{array}$ & \\
\hline
\end{tabular}

Satty and Kearns ${ }^{[42]}$

Elements in each level are compared in pairs with respect to their importance to an element in the next higher level. Starting at the top of the hierarchy and working down, the pair-wise comparisons at a given level can be reduced to a number of square matrices $\mathrm{A}=\left[\alpha_{\mathrm{ij}}\right]_{\mathrm{n} \times \mathrm{n}}$ as in the following:

$$
\left(\begin{array}{cccc}
a_{11} & a_{12} & \ldots & a_{1 n} \\
a_{21} & a_{22} & \ldots & a_{2 n} \\
\cdot & \cdot & & \cdot \\
a_{1 n} & a_{2 n} & \ldots & a_{n n}
\end{array}\right)
$$

The matrix has reciprocal properties, which are:

$$
\mathrm{a}_{\mathrm{ji}}=\frac{1}{\mathrm{a}_{\mathrm{ij}}}
$$

After all pair wise comparison matrices are formed, the vector of weights, $\mathrm{w}=\left[\mathrm{w}_{1}, \mathrm{w}_{2}, \ldots, \mathrm{w}_{\mathrm{n}}\right]$, is computed on the basis of Satty's eigenvector procedure. The computation of the weights involves two steps. First, the pair wise comparison matrix $\mathrm{A}=\left[\alpha_{\mathrm{ij}}\right]_{\mathrm{n} \times \mathrm{n}}$ is normalized by Eq. 1 and then the weights are computed by Eq. 2:

$$
\mathrm{a}_{\mathrm{ij}}{ }^{*}=\frac{\mathrm{a}_{\mathrm{ij}}}{\sum_{\mathrm{i}=1}^{\mathrm{n}} \mathrm{a}_{\mathrm{ij}}}
$$


for all $\mathrm{j}=1,2, \ldots, \mathrm{n}$

$$
w_{i}=\frac{\sum_{j=1}^{n} a_{i j}^{*}}{n}
$$

for all $\mathrm{I}=1,2, \ldots, \mathrm{n}$

Satty ${ }^{[41]}$ showed that there is a relationship between the vector weights, $\mathrm{w}$ and the pair-wise comparison matrix, A, as shown in Eq. 3:

$\mathrm{Aw}=\lambda_{\max } \mathrm{w}$

The $\lambda_{\max }$ value is an important validating parameter in AHP and is used as a reference index to screen information by calculating the Consistency Ratio (CR) of the estimated vector. To calculate the CR, the Consistency Index (CI) for each matrix of order $n$ can be obtained from Eq. 4:

$$
\mathrm{CI}=\frac{\lambda_{\max }-\mathrm{n}}{\mathrm{n}-1}
$$

Then, CR can be calculated using Eq. 5:

$$
\mathrm{CR}=\frac{\mathrm{CI}}{\mathrm{RI}}
$$

where, RI is the random consistency index obtained from a randomly generated pair-wise comparison matrix. Table 2 shows the value of the RI from matrices of order $1-10$ as suggested by Satty ${ }^{[4]}$. If $\mathrm{CR}<0.1$, then the comparisons are acceptable. If, however, $\mathrm{CR} \geq 0.1$, then the values of the ratio are indicative of inconsistent judgments. In such cases, one should reconsider and revise the original values in the pair wise comparison matrix A.

The AHP was adopted in education, engineering, government, industry, management, manufacturing, personal, political, social and sports ${ }^{[52]}$. The wide applicability is due to its simplicity, ease of use and great flexibility. It can be integrated with other techniques, for instance, mathematical programming in order to consider not only both qualitative and quantitative factors, but also some real-world resource limitations.

Table 2: Random inconsistency indices (ri) for $\mathrm{N}=10$

\begin{tabular}{lllllllllll}
\hline $\mathrm{N}$ & 1 & 2 & 3 & 4 & 5 & 6 & 7 & 8 & 9 & 10 \\
\hline $\mathrm{RI}$ & 0.00 & 0.00 & 0.58 & 0.9 & 0.12 & 1.24 & 1.32 & 1.41 & 1.46 & 1.49 \\
\hline Satty $^{[4]]}$ & & & & & & & & &
\end{tabular}

\section{MATERIALS AND METHODS}

Proposal process for measuring UQOL: As it noted already urban quality of life could have a broad meaning which creates room for different interpretations. So, to use this concept in urban planning needs an appropriate framework for measuring. The multi-criteria models could be used for measuring as they are simple to understand for application. Multi-criteria models are used in this research for urban quality of life measuring and investigation. The stages of proposed model are as follow:

An introduction to the subject and the area: The research started by an introduction of the case studies. This had an important role for definition of quality of life with its different dimensions in the study areas. However, these characters may have many similarities but there have been many differences which had to be considered in the first stage

Formulating the different dimensions of QOI for the case studies: The subject was studied by a search in the literature to provide the ground for better knowledge about quality of life. The case was further discussed with local experts for more accurate formulations of the criteria in the two case cities.

Indicators and criteria definition: The different dimensions of urban quality of life include major issues such as environmental quality, social environment quality. These issues can not be measured as they have an expanded meaning, so appropriate criteria and indicators could help for measuring.

The hierarchical chart of the subject: The aims, criteria and the alternatives should be shown by drawing a graph in the first step in a hierarchical process. Transferring the subject of study to a hierarchical structure is the most important part of the analytic hierarchical process.

Dimension weighting and the criteria: Devising an appropriate framework for weighting the dimensions and selected criteria is necessary for measuring quality of life, as they have no similar weights in general quality and vary in different places. For example in some of the advanced countries the social quality may gain more importance while environmental problems are the most important dimension of the quality of life in developing world. 
There are different models for weighing which each of then has their advantages and disadvantages. Here the group weighting of Professor Saaty in analytic hierarchical process is used which could be an appropriate framework for the participation of a broad range of expertise and local authorities in the process of weighting. The pair-wise comparative matrix are created when the research group agreed on the hierarchical process.

This method the analytic hierarchy gives the opportunity to each of decision maker to enter their view in the matrix and the single judge will changed to group judge (for pair-wise comparison) by using geometric mean. Aczel and Saaty ${ }^{[42]}$ have shown that geometric mean is the best method for integration of different judgments in the process of group analytic hierarchy.

Preference assignment of the alternatives: By using the pair-wise comparisons which could be in group, the preference of each place would be determined by the given criteria and indicators. It should be mentioned that the compatibility of judgments is investigated in each level of pair-wise comparisons in the previous stage. The judgments were reviewed when the figure was equal or more than the standard limit $(0.1)$.

Final scoring and ranking of alternatives: In this stage the final weight of each place would be determined by using the popular methods with respect to the weight of dimensions, criteria and the preference of alternatives. The level of quality of life would be ranked by the amount of scores which each place gained. Also a specific ranking could be done by the different dimensions of each place. This leads to a comprehensive view of different dimensions of the quality of life for planner in different places.

The research process: The present research has been conducted in the north of Iran by selecting two cities of Babol and Sari. These urban centers are located in the province of Mazandaran. The province covers an area of $24091.3 \mathrm{~km}^{2}$ which includes $1.4 \%$ of country's total area. About $50.6 \%$ population lived in urban areas in 2001. However the share of urban population is lower than the national level $(66.8 \%)$ but there is a potential for accelerating trend of urbanization due to its rural residents. Babol and Sari are two of largest city of the province which have important function in the region. Sari is the administrative center of the province and Babol is a commercial regional metropole. The latest census shows that Sari and Babol had 253209 and
193310 population in 2006 respectively. As it noted above the research is intended to provide an appropriate framework by using analytic hierarchical process for the participation of local urban authorities and experts.

In order to have a representative result, 50 experts were invited to participate in the judgment process in this research. They can be divided into two groups with 20 experts each. Group 1 is experienced urban planning and design practitioners i.e., architects, urban planners and property development managers having more than 15 years' working experiences in the construction in cases studies. These experts had quite good knowledge about the urban problems of the cities as each of them had specialized in urban field and experience. The second group were the citizen who had no professional knowledge and were impartial, but were involved with the city constrains due to their social position. For example local mosques clergies or the members of nongovernmental agencies.

They know the needs and wants of citizens well and therefore their views can represent the citizens' thinking to a large extent. The process of analytic hierarchy provided a good ground for using their views in the process of measuring the objective quality of life in the two cities.

Development of a hierarchical decision model: As mentioned before for application AHP method, it is necessary to develop a hierarchical decision model for the decision problem. The decision model of this study illustrated in Fig. 1 is broken into three major levels including goal level, objectives level and design criteria level. The goal level is the topmost level which describes the decision problem. This study attempts to objective measuring and comparing urban quality of life in selected case studies. The second level is the objectives level comprised of four aspects: physical quality, social quality, economical quality and environmental quality while the third level consists of various design criteria. In order to identify the priorities of three sustainable development objectives in the second level and the relative importance of different design criteria in the third level, a series of pair-wise comparisons have to be performed by the experts. The elements in both levels are then weighted and the final score for each potential renewal proposal is based on the composite view of a group of experts engaging in the judgment process. 


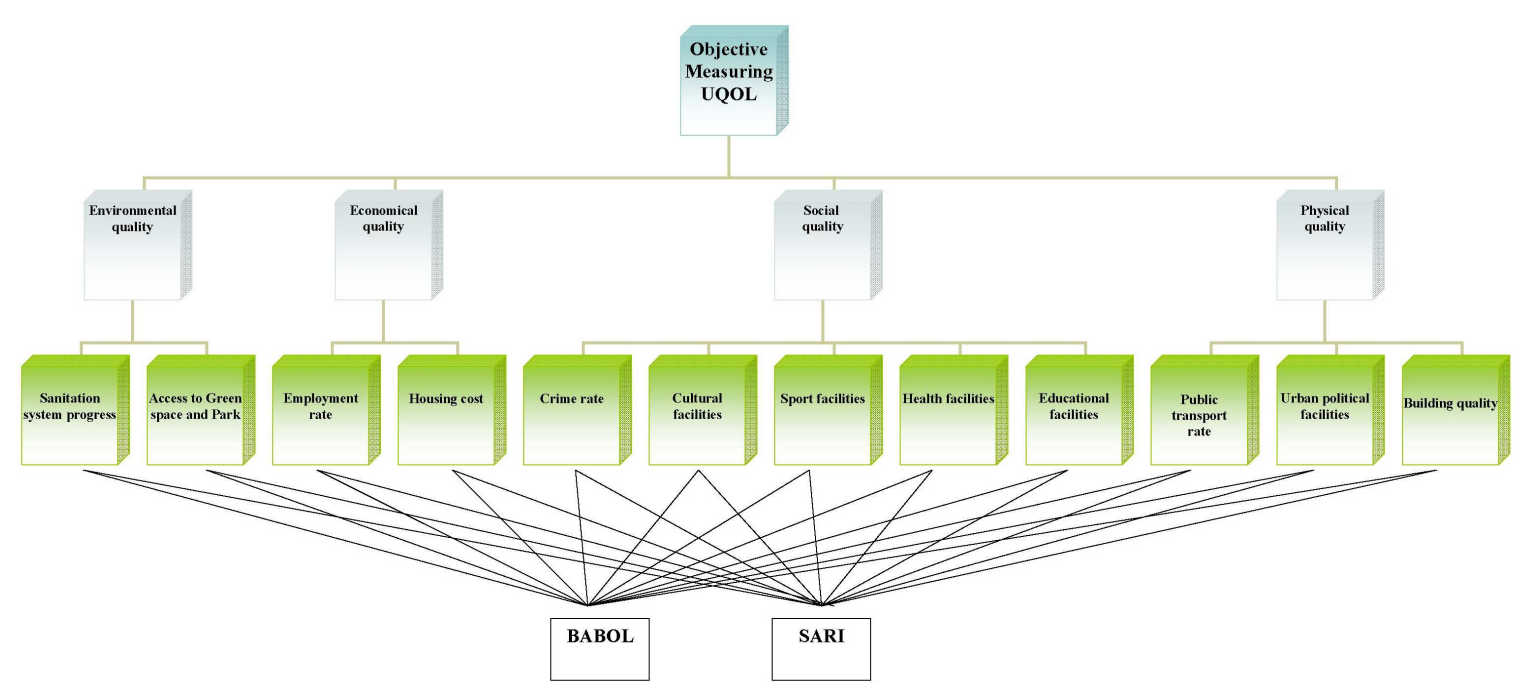

Fig. 1: AHP decision model for objective measuring urban quality of life

Selecting indicators: After determining dimensions of quality of life in the sample cities, some indicators should be selected for measuring as these dimensions are very general and can not measured by itself. Dwyer et al. ${ }^{[14]}$ believe that the most important characteristics of selected indicators are as follow:

Support concept: One of the important issues for indicator selection is that they should be able to response the needs of research questions.

Validity: Indicators must introduce the explained concepts in the model or should be a valuable alternative for the concept replacement.

Data availability and quality: The indicators should be extracted from a reliable source.

Sensitivity: Indicators are sensible in the course of time which this provides a ground for more understanding of details of measuring indicators.

Simplicity: Indicators are used to illustrate the concepts to a broad range of users, so despite their complexity, they should be perceived easily.

Quantitativenes: Indicators should be measured by the methods which are understood simply.

The indicators were considered in this stage as accessible in the two sample cities which it was one of the main limitations of the study. These indicators are indicated in Fig. 1 and Table 3.

The data of the indicators have been provided from the different statistical centers and police offices.
Table 3: Selected indicators

\begin{tabular}{lllll}
\hline Aspects & $\begin{array}{l}\text { Environmental } \\
\text { quality }\end{array}$ & $\begin{array}{l}\text { Economical } \\
\text { quality }\end{array}$ & $\begin{array}{l}\text { Social } \\
\text { quality }\end{array}$ & $\begin{array}{l}\text { Physical } \\
\text { quality }\end{array}$ \\
\hline Selected & Sanitation & Employment & Crime rate & Public \\
indicators & transport rate \\
& system progress & rate & & Urban political \\
& Access to green & Housing cost & Cultural & facilities \\
& space and park & & facilities & Sport facilities \\
& & & Building \\
& & healthy facilities & quality \\
& & & educational & \\
& & & facilities & \\
\hline
\end{tabular}

Computing the relative weights: During the interview, each expert is requested to take part in AHP judgment process with the aid of computer software called Expert Choice. By using this software, the relative weights of the objectives and corresponding criteria and the consistency ratios of the matrices can be calculated. If there is any matrix with an unacceptable CR value, the expert is required to make judgment on that matrix again. In order to improve the consistency in ratings, the experts can be explained about the concept of pairwise comparison. The rounded generic mean of each individual comparisons wear consider as final view the in next stage

Table 4-8 show the relative weights, Eigenvector and $\mathrm{CR}$ values for each of them.

In Table 2 and 4, four UQOL aspects (level 2 of the decision model) were rated pair by pair with respect to the decision problem (topmost level of the decision model). In Fig. 1, the selected indicators (level 3 of the decision model) were rated pair by pair in relation to their respective aspect (level 2 of the decision model). The last column of each matrix shows the eigenvectors indicating the absolute priority weight of each rated criterion. 
Table 4: Comparisons of four UQOL aspects

\begin{tabular}{llllll} 
& & & & & Eigenvector \\
\hline Physical quality & 1 & 4 & 6 & 2 & $0 / 482$ \\
Social quality & $1 / 4$ & 1 & 3 & $1 / 4$ & $0 / 12$ \\
Economical quality & $1 / 6$ & 4 & 1 & $1 / 6$ & $0 / 057$ \\
Environmental quality & $1 / 2$ & 4 & 6 & 1 & $0 / 341$ \\
\hline
\end{tabular}

$\mathrm{CR}=0 / 05$

Table 5: Pair-wise comparison for physical quality indicators

\begin{tabular}{lllll}
\hline & & & & Eigenvector \\
\hline $\begin{array}{l}\text { Building } \\
\text { quality }\end{array}$ & 1 & 4 & 7 & $0 / 696$ \\
$\begin{array}{l}\text { Urban political } \\
\text { facilities }\end{array}$ & $1 / 4$ & 1 & 4 & $0 / 229$ \\
Public transport rate & 1 & $1 / 4$ & $1 / 7$ & $0 / 075$ \\
\hline
\end{tabular}

CR $=0 / 07$

Table 6: Pair-wise comparison of social quality indicators

\begin{tabular}{lllllll}
\hline & & & & & & Eigenvector \\
\hline $\begin{array}{l}\text { Educational } \\
\text { facilities }\end{array}$ & 1 & $1 / 6$ & $1 / 3$ & 1 & $1 / 8$ & $0 / 046$ \\
$\begin{array}{l}\text { Healthy } \\
\text { facilities }\end{array}$ & 6 & 1 & 3 & 6 & $1 / 4$ & $0 / 242$ \\
$\begin{array}{l}\text { Sport } \\
\text { facilities }\end{array}$ & 3 & $1 / 3$ & 1 & 3 & $1 / 6$ & $0 / 107$ \\
$\begin{array}{l}\text { Cultural } \\
\text { facilities }\end{array}$ & 1 & $1 / 6$ & $1 / 3$ & 1 & $1 / 8$ & $0 / 046$ \\
Crime rate & 8 & 4 & 6 & 8 & 1 & $0 / 56$ \\
\hline $\mathrm{CR}=0 / 04$ & & & & & &
\end{tabular}

Table 7: Pair-wise comparison for economic quality indicators

\begin{tabular}{llll}
\hline & & & Eigenvector \\
\hline Housing cost & 1 & 1 & $0 / 5$ \\
Employment rate & 1 & 1 & $0 / 5$ \\
\hline
\end{tabular}

Table 8: Pair-wise comparison for environmental indicators

\begin{tabular}{lccc}
\hline \multicolumn{3}{l}{ Table 8: Pair-wise comparison for environmental indicators } \\
\hline $\begin{array}{l}\text { Access to green } \\
\text { space and park }\end{array}$ & 1 & $1 / 5$ & Eigenvector \\
$\begin{array}{l}\text { Sanitation system } \\
\text { progress }\end{array}$ & 5 & 1 & $0 / 167$ \\
\hline
\end{tabular}

By following the process, the alternatives (Babol and Sari cities) were pair-wise judgment of the group with respect to selected indicators. The main aim of the model was to measure and prioritize the urban quality of life in the two case study cities. The final score of each city could be computed by integration of relative weights of dimensions, criteria and alternatives for urban quality of life. The final weight was computed by Expert Choice and the final score of quality of life for Sari was 0.284 and for Babol the figure increased to 0.716 .

\section{RSULTS}

The results revealed that using analytic hierarchy process model creates opportunity to involving the different groups' views of urban users with respect to their duties and functions in the stage of criteria weighting. By considering to the flexibility of the model, the attitudes of local community could be integrated well to the decision making process. The results showed that despite the general expectation, urban quality of life was better in the smaller city of Babol compared to the administrative center of the province i.e., Sari. Such condition dictates the urban authorities to examine their plans and projects to promote the level of urban quality of life on the base of research realities not a crude reading.

\section{DISCUSSION}

The different dimensions of urban quality of life have been studied in the two cities and then the dimensions of physical, environmental, social and economic scored higher respectively. Such situations show the importance of provision of primary needs and services in the developing countries which are the main concerns of urban authorities and experts. The environmental quality is a very serious problem as it placed in the second rank for the urban quality life in the area. The area is one of the most concentrated zone in the north and now is facing sever environmental problems. The relative weights of each city could be computed in the line with selected indicators and criteria after pair-wise comparison. These weights can be very useful for sectoral planning which the local authorities intend to do in future. It means that all of the different scores of indicators could be compared and the urban resource and facilities allocate in an optimum way to increase the level of quality of life.

The ambition of 'quality of life' has been a focal point for planner in a certain place with certain person or group. Also it could be state that planning as general and public activity could upgrade the urban quality of life potentially.

The concept of quality of life could be exploited at least in stages of the process of urban planning. First stage is when planners try to have a correct and reliable perspective from the existed conditions of the city. In fact planners intend to specify the issues which have more priorities, so knowledge about the different dimensions of quality of life is an appropriate guide in this stage. Second stage is when the projects and plans should be investigated to be confirmed for their efficiency and usefulness. In this stage the impact of different projects on the quality of life could be very important for the planner and decision makers. Clearly plans and projects with more efficiency which increase the urban quality of life and especially be able to upgrade the aspects of planner's concerns, would be accepted by the urban planners. 
As it was discussed in the literature review, urban quality of life is a multi-dimensional concept. Most of the researchers are agreed that this concept included from two dimensions as objective and subjective. However, these dimensions have many common similarities in different places but in a specific place the certain characteristics of the new location should be considered carefully for measuring the quality of life.

\section{CONCLUSION}

Since the concept of quality of life is multidimensions and involves with many indicators, the multi criteria analyze models are able to provide an appropriate fretwork for measuring and investigation. In the process of multi-criteria decision making, the views of different groups could be considered in the stage of indicator weighting. So, this process can help to maximize public participation in urban decision making.

Also the model has a clear process and feasible, it could be used for multi aspects analyze of urban quality of life concept. For example by applying the model on the two northern cities, the dimensions of quality of life, the importance of them and the preference of each city was determined which the results could be interpreted. In other words local planners and authorities can direct the scarce resources towards the aspects of quality of life which are more important and the city gained fewer score in the process of investigation. So the better allocation and distribution of resources lead to increase of urban quality of life. In the end it needs to be mentioned that the aim of research has been to show the level of quality of life in two sample cities. Obviously to interpret and find the reasons for the different results of two cities could be done in another study.

\section{ACKNOWLEDGMENT}

The researchers would like to appreciate the vicechancellor of research of Mazandaran University for their financial supports.

\section{REFERENCES}

1. Banai, R., 2005. Anthropocentric problem solving in planning and design, with analytic hierarchy process. J. Arch. Plann. Res., 22: 107-120. http://direct.bl.uk/bld/PlaceOrder.do?UIN=169190 $608 \&$ ETOC $=$ RN $\&$ from $=$ searchengine

2. Blomquist, G.C., M.C. Berger and J.P. Hoehn, 1988. New estimates of quality of life in urban areas. Am. Econ. Rev., 78: 89-107. http://www.jstor.org/stable/1814700
3. Boyer, R. and D. Savageau, 1981. Places Rated Almanac, Rand McNelly, Chicago, ISBN: 9780470089590, p: 650.

4. Chen, C.F., 2006. Applying the Analytical Hierarchy Process (AHP) approach to convention site selection. J. Travel Res., 45: 167-174. http://jtr.sagepub.com/cgi/reprint/45/2/167

5. Cheng, E.W.L., H. Li and L. Yu, 2005. The Analytic Network Process (ANP) approach to location selection: A shopping mall illustration. Construct. Innovat., 5: 83-97. DOI: 10.1108/14714170510815195

6. Cicerchia, A., 1999. Measures of optimal centrality: Indicators of city effect and urban overloading. Soc. Indicat. Res., 46: 276-299. http://cat.inist.fr/?aModele $=$ afficheN\&cpsidt $=2014377$

7. Clark, D.E. and R. James Kahn, 1988. The social benefits of urban cultural amenities. J. Region. Sci., 28: 363-377. DOI: $10.1111 / \mathrm{j} .1467-$ 9787.1988.tb01088.x

8. Cook, T., P. Falchi and R. Mariano, 1984. An urban allocation model combining time series and analytic hierarchical methods. Manage. Sci., 30: 198-208. DOI: $10.1287 / \mathrm{mnsc} .30 .2 .198$

9. Crouch, G. and J.R. Ritchie, 2005. Application of the analytic hierarchy process to tourism choice and decision making: A review and illustration applied to destination competitiveness. Tour. Anal. 10: $17-25$.

http://direct.bl.uk/bld/PlaceOrder.do?UIN=174456 $511 \&$ ETOC $=$ RN \& from $=$ searchengine

10. Davidson, W.B. and P.R. Cotter, 1991. The relationship between sense of community and subjective well-being: A first look. J. Commun. Psychol., 19: 246-253. http://www3.interscience.wiley.com/journal/11240 8541/abstract

11. De Montis, A., P. De Toro, B. Droste-Franke, I. Omann and S. Stagl, 2000. Criteria for quality assessment of MCDA methods. Proceedings of the 3rd Biennial Conference of the European Society for Ecological Economics, May 3-6, ESEE, Vienna, pp: 1-30. http://www.wuwien.ac.at/project/esee2000/PapersPDF/H298.pdf

12. Diener, E. and E. Suh, 1997. Measuring quality of life: Economic, social and subjective indicators. Soc. Indicat. Res., 40: 189-216. http://cat.inist.fr/?aModele $=$ afficheN\&cpsidt $=2871608$

13. Dissart, J. and S. Deller, 2000. Quality of life in the planning literature. J. Plann. Literat., 15: 135-161. DOI: $10.1177 / 08854120022092962$ 
14. Dwyer, A., C. Zoppou, O. Nielsen, S. Day and S. Roberts, 2004. Quantifying social vulnerability: A methodology for identifying those at risk to natural hazards. GeoCat No. 61168, Geoscience, Australia. http://www.ga.gov.au/image_cache/GA4267.pdf

15. Eastman, J.R., A.K. Kyem and J. Toledano, 1993. A procedure for multi-objective decision making in GIS under conditions of conflicting objectives. Proceedings of the 4th European Conference on Geographic Information Systems, Mar. 29-Apr. 1, Genoa, Italy, pp: 438-447.

http://training.esri.com/campus/library/Bibliograph $\mathrm{y} /$ RecordDetail.cfm?ID $=10450$

16. Giannias, D.A., 1996. Quality of life in southern Ontario. Can. J. Region. Sci., 19: 213-23. http://direct.bl.uk/bld/PlaceOrder.do?UIN=040811 904\&ETOC $=$ RN\& from $=$ searchengine

17. Grayson, L. and K. Young, 1994. Quality of Life in Cities: On Overview and Guide to the Literature. The British Library, London, ISBN: 0712308016, pp: 148.

18. Harker, P.T. and L. Vargas, 1987. The theory of ratio scaled estimated: Satty's analytical hierarchy process. Manage. Sci., 33: 1385-1403. http://cat.inist.fr/?aModele $=$ afficheN\&cpsidt $=7655738$

19. Higgs, G., 2006. Integrating multi-criteria techniques with geographical information systems in waste facility location to enhance public participation. J. Waste Manage. Res., 24: 105-117. DOI: $10.1177 / 0734242 X 06063817$

20. Ho, W., 2008. Integrated analytic hierarchy process and its applications-A literature review. Eur. J. Operat. $\quad$ Res., 186 : 211-228. http://cat.inist.fr/?aModele=afficheN\&cpsidt=20016160

21. Kangas, J., 1992. Multiple-use planning of forest resources by using the analytic hierarchy process. Scandinavian J. For. Res., 7: 259-268. http://www.fao.org/agris/search/display.do?f=./199 2/v1814/SE9200290.xml;SE9200290

22. Kennedy, P., 1993. Preparing for the Twenty-first Century, Random House, New York, ISBN: 0679747052, pp: 448.

23. Lee, J.K.L. and E.H.W. Chan, 2008. The Analytic Hierarchy Process (AHP) approach for assessment of Urban renewal proposals. Soc. Indicat. Res., 89: 155-168. DOI: 10.1007/s11205-007-9228-X

24. Lee, W.B., H. Lau, Z. Liu and S. Tam, 2001. A fuzzy analytical hierarchy process approach in modular product design. Expert Syst., 18: 32-42. DOI: 10.1111/1468-0394.00153

25. Liu, B.C., 1976. Quality of Life Indicators in US metropolitan Areas: A Statistical Analysis. Praeger, New York, ISBN: 13: 9780275563608.
26. Ludin, A.N.M., A. Yaakup, S.Z. AbuBakar, A. Maidin and H. Ramle, 2006. GIS and planning support system for klang valley region, Malaysia. Proceedings of the ASIA GIS 2006, International Conference, Mar. 9-10, Johor, Malaysia. http://www.gisdevelopment.net/proceedings/mapas ia/2006/Agriculture $\% 20$ and $\% 20$ Precision \%20Farm ing/index.htm

27. Malczewski, J., 1999. GIS and Multi-criteria Decision Analysis. John Wiley, Toronto, ISBN: 978-0-471-32944-2, pp: 408.

28. Massam, B.H., 2002. Quality of life: Public planning and private living. Prog. Plann., 58: 141-227. http://linkinghub.elsevier.com/retrieve/pii/S030590 0602000235

29. McCall, S., 1975. Quality of life. Soc. Indicat. Res., 2: 229-248. DOI: 10.1007/BF00300538

30. McCrea R., R. Stimson and J. Western, 2005. Testing a moderated model of satisfaction with urban living using data for brisbane-South East Queensland. Australia. Soc. Indicat. Res., 72: 121-152. http://cat.inist.fr/?aModele $=$ afficheN\&cpsidt $=17078638$

31. McCrea, R., T. Shyy and R. Stimson, 2006. What is the strength of the link between objective and subjective indicators of urban quality of life. Applied Res. Q. Life, 1: 79-96. http://espace.library.uq.edu.au/view/UQ:79298

32. Megone, C., 1990. The Quality of Life: Starting from Aristotle. In: Quality of Life: Perspectives and Policies, Baldwin, S., C. Godfrey and C. Propper (Eds.). Biddles, London, ISBN: 0415095816, pp: 28-41.

33. Michalos, A.C. and B.D. Zumbo, 1999. Public services and the quality of life. Soc. Indicat. Res., 48: 125-156. DOI: 10.1023/A:1006893225196

34. Muralidhar, K., R. Santhanam and R.L. Wilson, 1990. Using the analytic hierarchy process for information system project selection. Inform. Manage., 18: 87-95. http://portal.acm.org/citation.cfm?id=80441

35. Myers, D., $1987 . \quad$ Community-relevant measurement of quality of life: A focus on local trends. Urban Affairs Q., 23: 108-125. http://wwwrcf.usc.edu/ dowell/pdf/community.pdf

36. O'Brien, D.J. and S. Ayidiya, 1991. Neighborhood community and life satisfaction. J. Comm. Develop. Soc., 22: 20-37.

http://www.accessmylibrary.com/coms2/browse_JJ _J083_151_225

37. Partovi, F.Y., 1992. Determining what to benchmark: An analytic hierarchy process approach. Int. J. Operat. Prod., Manage., 14: 25-39. DOI: $10.1108 / 01443579410062068$ 
38. Phua, M.H. and M. Minowa, 2005. A GIS-based multi-criteria decision making approach to forest conservation planning at a landscape scale: A case study in the Kinabalu Area Sabah, Malaysia. J. Landscape Urban Plann., 71: 207-222. DOI: 10.1016/j.landurbplan.2004.03.004

39. Richards, R., B. O'leary and K. Mutsunziwa, 2007. Measuring quality of life in informal settlements in South Africa. Soc. Indicat. Res., 81: 375-388. http://cat.inist.fr/?aModele $=$ afficheN\&cpsidt $=18629499$

40. Santos, L.D. and I. Martins, 2007. Monitoring Urban quality of life: The porto experience. Soc. Indicat. $\quad$ Res., $\quad 80$ 4 411-425. http://cat.inist.fr/?aModele $=$ afficheN\&cpsidt $=1848$ 0995

41. Satty, T.L., 1980. Analytic Hierarchy Process. New York, McGraw-Hill, ISBN: 096203178X, pp: 320

42. Satty, T.L. and K.P. Kearns, 1985. Analytical Planning: The Organization of Systems. Pergamon, Oxford, ISBN: 0080325998, pp: 212.

43. Schwirian, K.P., A.L. Nelson and P.M. Schwirian, 1995. Modeling urbanism-economic, social and environmental-stress in cities. Soc. Indicat. Res., 35: 201-223. DOI: 10.1007/BF01079027

44. Shen, Q., K.K. Lo and Q. Wang, 1998. Priority setting in maintenance: A modified multi-attribute approach using analytical hierarchy process. Construct. Manage. Econ., 16: 693-702. http://ideas.repec.org/a/taf/conmgt/v16y1998i6p69 3-702.html

45. Sirgy, M.J., D.R. Rahtz, M. Cicic and R. Underwood, 2000. A method for assessing residents' satisfaction with community-based services: A quality-of-life perspective. Soc. Indic. Res., 49: 279-316. http://cat.inist.fr/?aModele=afficheN\&cpsidt $=1549688$

46. Sirgy, M.J. and T. Cornwell, 2001. Further validation of the Sirgy et al.'s measure of community quality of life. Soc. Indicat. Res., 56:125-143. http://cat.inist.fr/?aModele $=$ afficheN\&cpsidt $=1421$ 2225
47. Sufian, A.J.M., 1993. A multivariate analysis of the determinants of urban quality of life in the world's largest metropolitan areas. Urban Stud., 30: 1319-1329. DOI: $10.1080 / 00420989320081281$

48. Stover, M.E. and C.L. Leven, 1992. Methodological issues in the determination of the quality of life in urban areas. Urban Stud., 29: 737-754. DOI: 10.1080/00420989220080671

49. Turksever, A.N. and G. Atalic, 2001. Possibilities and limitations for the measurement of the quality of life in urban areas. Soc. Indicat. Res., 53: 163-187. http://cat.inist.fr/?aModele $=$ afficheN\&cpsidt $=14205019$

50. Ulengin, B. F. Ulengin and U. Guvenc, 2001. A multidimensional approach to urban quality of life: The case of Istanbul. Eur. J. Operat. Res., 130: 361-374. DOI: 10.1016/S0377-2217(00)00047-3

51. UNDP, 1994. Human Development Report. Oxford University Press, New York, ISBN: 0195091701, pp: 240 .

52. Vaidya, O.S. and S. Kumar, 2006. Analytic hierarchy process: An overview of applications. Eur. J. Operat. Res., 169: 1-29. http://cat.inist.fr/?aModele $=$ afficheN\&cpsidt $=1751$ 7006

53. Wish, N.B., 1986. Are we really measuring the quality of life? Well-being has subjective dimensions, as well as objective ones. Am. J. Econ. Sociol., 45: 93-99. DOI: 10.1111/j.15367150.1986.tb01906.x

54. Yuksel, I. and M. Dagdeviren, 2007. Using the Analytic Network Process (ANP) in a SWOT analysis-A case study for a textile firm. J. Inform. Sci., 177: 3364-3382. DOI: 10.1016/j.ins.2007.01.001 